\title{
PENGARUH KROM PADA ELEKTRODEPOSISI NIKEL DARI LARUTAN NIKEL-KROM
}

\author{
Pramujo Widiatmoko*, Isdiriayani Nurdin \\ Program Studi Teknik Kimia, Fakultas Teknologi Industri \\ Institut Teknologi Bandung \\ Jalan Ganesha no 10, Bandung 40132 \\ Email: pramujo.widiatmoko@che.itb.ac.id
}

\begin{abstract}
Abstrak
Elektrodeposisi merupakan metode alternatif yang potensial untuk mengurangi kandungan nikel dari limbah elektroplating sekaligus meningkatkan nilai ekonomisnya, dengan produk berupa logam nikel murni. Penelitian ini bertujuan mengkuantifikasi pengaruh krom dalam proses pemulihan nikel dari larutan limbah industri yang mengandung nikel dan krom. Nikel sulfat dan krom sulfat digunakan sebagai pendekatan larutan hasil ekstraksi limbah padat. Percobaan dilakukan pada tekanan dan temperatur ruang dengan variasi rasio krom terhadap nikel serta konsentrasi asam borat sebagai aditif. Hasil percobaan menunjukkan bahwa keberadaan krom dengan rasio $\mathrm{Cr} / \mathrm{Ni} 28,9 \%$ meningkatkan polarisasi aktivasi sekitar

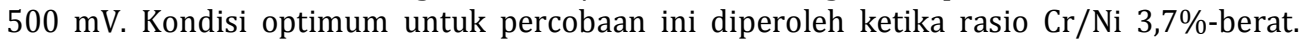
Perubahan rasio $\mathrm{Cr} / \mathrm{Ni}$ dalam larutan dari 3,7\% menjadi 14,8\% menurunkan efisiensi arus sebesar $57 \%$, menurunkan efisiensi deposisi $5 \%$, serta meningkatkan kebutuhan energi hingga 8,3\%. Morfologi deposit nikel menjadi lebih buruk dengan kenaikan rasio $\mathrm{Cr} / \mathrm{Ni}$, dan berubah menjadi deposit hidroksida pada rasio $\mathrm{Cr} / \mathrm{Ni} \mathrm{14,8 \%}$.
\end{abstract}

Kata kunci: elektrodeposisi nikel, larutan nikel-krom, krom, limbah elektroplating

\begin{abstract}
Electrodeposition, which can convert nickel ion into pure nickel metal, is an alternative for reducing nickel concentration in electroplating waste and in same time increasing its economic value. The aim of this research is to study the effect of chromiun presence on the performance of Nickel recovery from liquid waste of $\mathrm{Ni}-\mathrm{Cr}$ electroplating process. Liquid of electroplating waste leachate is represented by solutions containing nickel and chromium sulfate method.. All experiments were carried out at ambient temperature and pressure with $\mathrm{Cr} / \mathrm{Ni}$ rasio and boric acid composition as variables. Result of the research shows that chromium presence in solution with $28.9 \% \mathrm{Cr} / \mathrm{Ni}$ ratio increases activation polarization of about $500 \mathrm{mV}$. Optimum condition of the experiment is obtained for $\mathrm{Cr} / \mathrm{Ni}$ ratio $3.7 \%-\mathrm{w}$. Increasing $\mathrm{Cr} / \mathrm{Ni}$ ratio from $3.7 \%$ to $14.8 \%$ decreases current efficiency by $57 \%$ and deposition efficiency by $5 \%$, and also increases energy consumption by $8.3 \%$. Morfology of deposited nickel deteriorates with increasing of $\mathrm{Cr} / \mathrm{Ni}$ ratio and hidroxide compound is formed when it reaches $14.8 \%$.
\end{abstract}

Keywords: nickel electrodeposition, nickel-chromium solution, chromium, electroplating waste

*korespondensi 


\section{Pendahuluan}

Nikel banyak digunakan di industri, baik sebagai bahan konstruksi, paduan baja, katalis, maupun pelapis logam lain. Limbah yang mengandung nikel dari industriindustri tersebut dikategorikan sebagai bahan berbahaya sehingga memerlukan penanganan lebih lanjut agar tidak mencemari lingkungan. Kandungan nikel yang cukup besar di dalam limbah, terutama limbah katalis dan limbah industri pelapisan, serta nilai ekonomis nikel yang relatif tinggi memungkinkan pemulihan nikel melalui jalur elektrodeposisi menjadi ekonomis.

Salah satu kendala yang dihadapi pada pengendapan nikel dari larutan limbah, terutama dari industri elektroplating, adalah keberadaan ion krom dalam larutan. Efisiensi arus akan turun dengan naiknya konsentrasi krom (III) dalam larutan elektrolit. Penurunan maksimum diperoleh pada konsentrasi krom 100 mg.dm ${ }^{-3}$ yaitu sebesar 10\% hingga 13\% (Mohanty dkk., 2002). Mengingat potensi pemulihan nikel dari limbah elektroplating, penelitian ini diarahkan pada pemahaman kuantitatif pengaruh krom terhadap elektrodeposisi nikel dari limbah tersebut.

Proses elektrodeposisi nikel merupakan reaksi elektrokimia, melibatkan elektron yang dipasok oleh sumber arus listrik searah. Reaksi tersebut terjadi di permukaan elektroda. Ion nikel dari larutan akan tereduksi membentuk lapisan logam nikel di katoda, sementara di anoda akan terjadi reaksi oksidasi dan terbentuk gas oksigen. Elektrolit berfungsi sebagai media penghantar muatan listrik yang dibawa oleh ion-ion tersebut.

Berdasarkan tabel potensial standar (Jones, 1992) potensial reduksi standar ion nikel (II) menjadi logam nikel adalah $-0,23$ volt terhadap elektroda standar hidrogen $(\mathrm{SHE}=$ Standard Hydrogen Electrode $)$. Sementara itu, potensial reduksi standar oksigen pada kondisi asam adalah +1.23 volt/SHE (Pletcher, 1990). Secara keseluruhan, reaksi tersebut dapat dituliskan sebagai berikut:

$$
\begin{array}{ll}
2 \mathrm{Ni}^{2+}+4 \mathrm{e} \rightarrow 2 \mathrm{Ni} & \mathrm{E}^{\mathrm{o}}=-0,23 \mathrm{~V} / \mathrm{SHE} \\
2 \mathrm{H}_{2} \mathrm{O} \rightarrow \mathrm{O}_{2}+4 \mathrm{H}^{+}+4 \mathrm{e} & \mathrm{E}^{o}=1,23 \mathrm{~V} / \mathrm{SHE}
\end{array}
$$

Dengan demikian, potensial standar sel untuk elektrodeposisi nikel adalah $-1,46$ volt terhadap SHE.
Berdasarkan Hukum Faraday, massa logam nikel yang terbentuk di katoda sebanding dengan besar muatan listrik yang dialirkan dan sebanding dengan berat ekivalen kimia dari senyawa tersebut (Prentice, 1991). Persamaan tersebut secara matematis dituliskan sebagai berikut:

$\mathrm{m}=(\mathrm{Mr} / \mathrm{n}) \times(\mathrm{It} / \mathrm{F})$

Potensial reduksi krom (III) menjadi logam krom sebesar $-0,74$ volt sehingga potensial standar sel untuk reaksi deposisi krom tersebut adalah -1.97 volt. Dengan perbedaan potensial standar sebesar 0,51 V dengan nikel, ion krom yang ada dalam larutan elektrolit dapat ikut tereduksi selama proses elektrodeposisi nikel.

\section{Metodologi}

Percobaan dilakukan dalam sel elektrokimia dengan titanium sebagai katoda. Elektrolit yang terdiri dari larutan nikel sulfat 12,5 g/L dan krom sulfat, dengan konsentrasi yang divariasikan, dilarutkan ke dalam aqua DM bersama dengan aditif berupa natrium sulfat sebanyak $60 \mathrm{~g} / \mathrm{L}$, magnesium sulfat $6 \mathrm{~g} / \mathrm{L}$, dan asam borat dengan variasi konsentrasi. Selanjutnya, larutan tersebut diaduk hingga semua bahan larut. Listrik searah dari rectifier dialirkan ke elektroda yang tercelup sepenuhnya di dalam cairan elektrolit tersebut pada tegangan kerja yang lebih besar daripada potensial standar sel, yaitu 2 volt. Percobaan dilakukan pada temperatur dan tekanan ruang.

Data percobaan yang diukur adalah arus listrik, tegangan kerja, serta massa nikel yang terdeposisi. Massa deposit nikel diukur dengan cara menimbang massa katoda awal dan massa katoda setelah deposisi, kemudian dihitung selisihnya. Arus listrik dan tegangan sel diukur dengan amperemeter dan voltmeter. Parameter yang dijadikan acuan dalam unjuk kerja proses ini adalah efisiensi arus dan konsumsi energi, serta perolehan kembali logam nikel yang dinyatakan dalam efisiensi deposisi.

Larutan nikel sulfat dan krom sulfat digunakan sebagai pendekatan dari larutan limbah industri yang ingin diteliti. Konsentrasi asam borat, aditif yang berperan penting dalam proses deposisi nikel, divariasikan untuk mengetahui pengaruh keberadaan krom terhadap kebutuhan aditif. Sementara itu, konsentrasi krom dalam 
larutan dinyatakan dalam rasio massa krom:nikel.

\section{Hasil dan Pembahasan}

Percobaan elektrodeposisi nikel dengan menggunakan larutan nikel mengandung krom memperlihatkan hasil yang berbeda secara signifikan dibandingkan dengan menggunakan larutan nikel saja. Berikut dibahas pengaruh krom terhadap kurva polarisasi, kebutuhan aditif, efisiensi arus, efisiensi deposisi, kebutuhan energi, serta morfologi deposit nikel.

\subsection{Pengaruh Krom terhadap kurva polarisasi}

Hal pertama yang dapat diamati dengan adanya krom dalam larutan adalah perubahan kurva polarisasi, sebagaimana terlihat pada Gambar 1. Percobaan dilakukan menggunakan larutan dengan rasio $\mathrm{Cr} / \mathrm{Ni}$ sesuai konsentrasi dalam limbah elektroplating yaitu 28,9\%. Keberadaan krom meningkatkan polarisasi aktivasi, yaitu energi awal yang dibutuhkan untuk memulai reaksi. Polarisasi aktivasi ini dihitung berdasarkan selisih antara potensial sel ketika reaksi mulai terjadi dengan potensial standar sel. Pada larutan nikel tanpa krom, polarisasi aktivasi sangat kecil. Reaksi mulai terjadi pada potensial $-1,5 \mathrm{~V}$, yaitu ketika arus listrik mulai terukur, sementara potensial standar sel nikel sebesar $-1,46 \mathrm{~V}$. Dengan keberadaan krom pada larutan nikel, tegangan yang diperlukan untuk memulai reaksi terlihat meningkat $500 \mathrm{mV}$ mendekati potensial sel standar krom yaitu -1,97 V. Hal ini mengindikasikan adanya hambatan kinetik dari reduksi $\mathrm{Cr}$ (III) yang terlihat sebagai peningkatan polarisasi aktivasi di permukaan katoda.

\subsection{Pengaruh Krom terhadap kebutuhan aditif}

Krom juga berpengaruh terhadap konsentrasi aditif yang dibutuhkan untuk memperoleh logam nikel. Semakin tinggi konsentrasi krom, jumlah aditif yang diperlukan akan semakin besar. Aditif yang paling signifikan pengaruhnya adalah asam borat yang berperan sebagai buffer $\mathrm{pH}$ untuk mencegah pasivasi permukaan katoda selama proses reduksi nikel (Yin dan Lin, 1996). Hal ini karena selama proses elektrodeposisi, peningkatan $\mathrm{pH}$ lokal terjadi di permukaan katoda yang memungkinkan terbentuknya senyawa hidroksida.

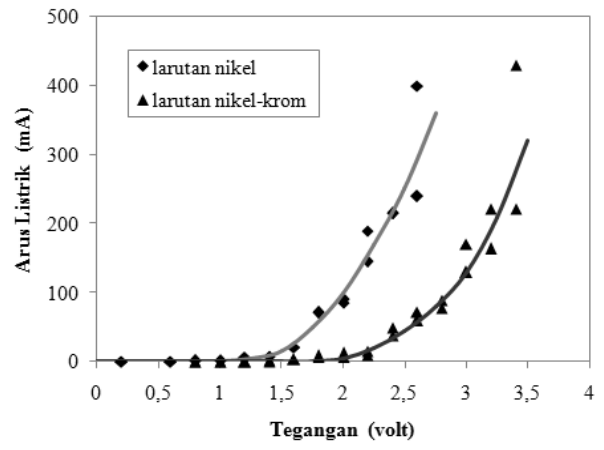

Gambar 1. Pengaruh keberadaan krom dengan rasio $\mathrm{Cr} / \mathrm{Ni} 28,9 \%$ terhadap kurva polarisasi

Berdasarkan data hasil kali kelarutan yang disajikan pada Tabel 1, senyawa krom (III) hidroksida jauh lebih mudah mengendap dibandingkan dengan nikel hidroksida. Peningkatan konsentrasi ion $\mathrm{OH}^{-}$seiring dengan kenaikan $\mathrm{pH}$ larutan tersebut menyebabkan kelarutan ion krom menurun. Endapan senyawa krom kemudian bereaksi lebih lanjut dengan air membentuk krom heksaaqua dan menutup permukaan katoda. Dengan penambahan asam borat sebagai buffer $\mathrm{pH}$, pembentukan senyawa hidroksida tersebut dapat dicegah.

Tabel 1. Hasil kali kelarutan, Ksp senyawa Krom dan Nikel Hidroksida

\begin{tabular}{lc}
\hline Senyawa & Ksp \\
\hline krom (III) hidroksida & $6,3 \times 10^{-31}$ \\
krom (II) hidroksida & $2,0 \times 10^{-16}$ \\
nikel (II) hidroksida & $2,0 \times 10^{-15}$
\end{tabular}

Sumber:

http://www.csudh.edu/oliver/chemdata/data-

ksp.htm

Pada rasio krom: nikel tertentu, konsentrasi asam borat minimum yang diperlukan juga tertentu. Apabila konsentrasi asam borat kurang dari konsentrasi minimum tersebut, endapan nikel yang terbentuk akan mengandung pengotor. Larutan dengan rasio krom:nikel 0,93\% membutuhkan asam borat minimum sebanyak 12 g/L. Sementara itu, asam borat $36 \mathrm{~g} / \mathrm{L}$ dapat digunakan untuk elektrodeposisi nikel dari larutan dengan rasio krom:nikel sampai 7,4\%.

Berdasarkan hasil analisis XRD seperti terlihat pada Gambar 2 dan 3, dengan konsentrasi asam borat $12 \mathrm{~g} / \mathrm{L}$, deposit nikel yang terbentuk dari larutan dengan rasio krom:nikel $\quad 0,46 \%$ dan $0,93 \%$ masih 
bercampur dengan pengotor. Dengan kenaikan konsentrasi asam borat menjadi 36 $\mathrm{g} / \mathrm{L}$, nikel yang relatif murni dapat dielektrodeposisi dari larutan dengan rasio krom:nikel 1,85\%, seperti terlihat pada Gambar 4. Penambahan konsentrasi krom menjadi $7,4 \%$ menyebabkan timbulnya kembali pengotor di dalam deposit, sebagaimana dapat dilihat pada Gambar 5 . Hal ini menunjukkan bahwa konsentrasi krom dalam larutan akan berpengaruh terhadap kebutuhan aditif, terutama asam borat.

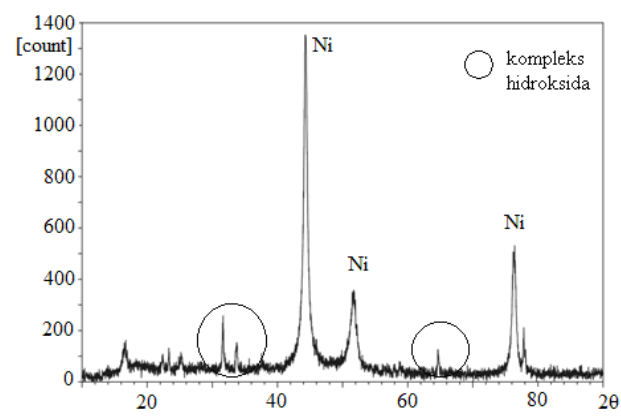

Gambar 2. Analisis XRD deposit nikel untuk $\mathrm{H}_{3} \mathrm{BO}_{3} 12 \mathrm{~g} / \mathrm{L}$, rasio $\mathrm{Cr} / \mathrm{Ni} \mathrm{0,46 \%}$

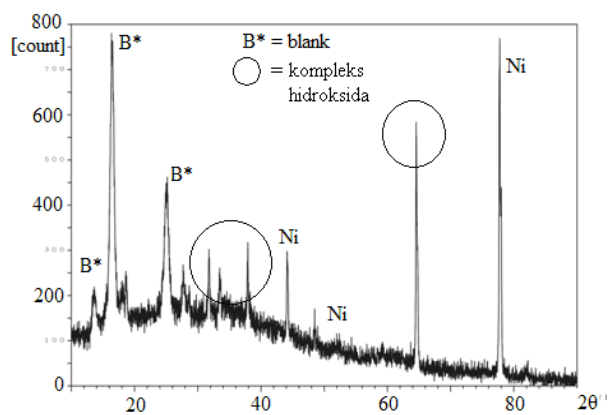

Gambar 3. Analisis XRD deposit nikel untuk $\mathrm{H}_{3} \mathrm{BO}_{3} 12 \mathrm{~g} / \mathrm{L}$, rasio $\mathrm{Cr} / \mathrm{Ni}$ 0,93\%

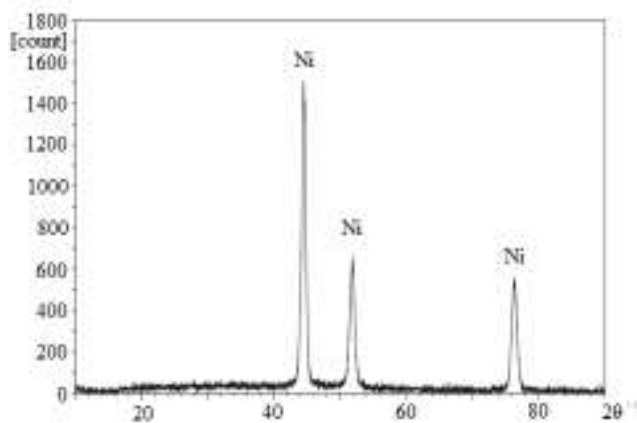

Gambar 4. Analisis XRD deposit nikel untuk $\mathrm{H}_{3} \mathrm{BO}_{3} 36 \mathrm{~g} / \mathrm{L}$, rasio $\mathrm{Cr} / \mathrm{Ni} \mathrm{1,85 \%}$

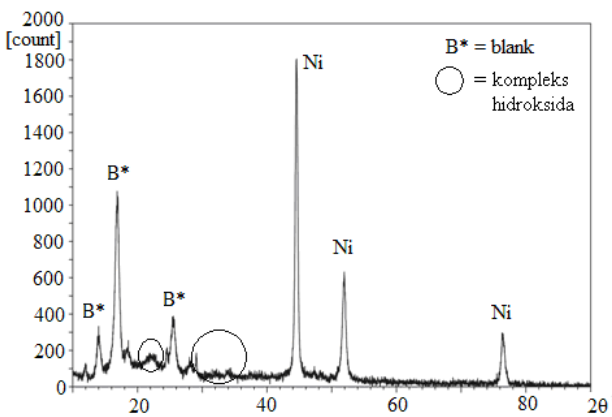

Gambar 5. Analisis XRD deposit nikel untuk $\mathrm{H}_{3} \mathrm{BO}_{3} 36 \mathrm{~g} / \mathrm{L}$, rasio $\mathrm{Cr} / \mathrm{Ni} \mathrm{7,4 \%}$

\subsection{Pengaruh krom terhadap efisiensi arus}

Efisiensi arus, yang dinyatakan sebagai rasio antara massa deposit nikel yang terbentuk dengan massa deposit nikel teoritis yang dihitung dari persamaan Faraday, juga terpengaruh oleh keberadaan krom. Hasil percobaan dengan berbagai variasi konsentrasi krom dapat dilihat pada Gambar 6.

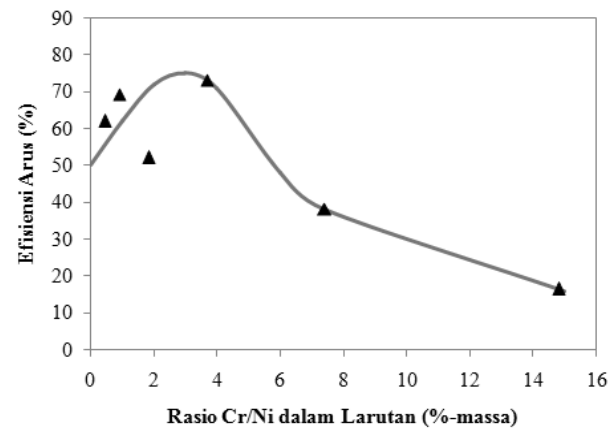

Gambar 6. Pengaruh rasio $\mathrm{Cr} / \mathrm{Ni}$ terhadap efisiensi arus

Efisiensi arus mula-mula naik seiring dengan kenaikan konsentrasi krom hingga mencapai rasio krom : nikel 3,7\%. Pada konsentrasi krom yang lebih tinggi, efisiensi turun drastis dari sekitar 70\% menjadi hanya $16 \%$ pada rasio krom:nikel 14,8\%. Penurunan efisiensi tersebut menunjukkan bahwa fraksi arus listrik yang digunakan untuk mereduksi ion nikel menjadi logam nikel berkurang. Selama percobaan, pembentukan gelembung di permukaan katoda tidak kentara sehingga disimpulkan bahwa penurunan efisiensi tersebut tidak disebabkan oleh pembentukan gas hidrogen sebagai reaksi reduksi kompetitor.

Pembentukan ion hidroksida di permukaan katoda diduga menjadi faktor 
utama berkurangnya massa nikel yang diperoleh. Hal ini dimungkinkan karena percobaan dilakukan dengan mengatur $\mathrm{pH}$ elektrolit di daerah pH 4 sampai pH 5. Reaksi elektrolisis dapat menyebabkan kenaikan $\mathrm{pH}$ lokal hingga mencapai daerah netral. Pada daerah ini, kemungkinan terbentuknya ion hidroksida di daerah permukaan katoda sangat tinggi.

\subsection{Pengaruh krom terhadap efisiensi deposisi}

Waktu optimum elektrodeposisi nikel yang diperoleh melalui percobaan adalah satu jam. Oleh karena itu, efisiensi deposisi didefinisikan sebagai massa nikel yang diperoleh dari elektrodeposisi selama satu jam dibandingkan dengan massa nikel dalam larutan. Gambar 7 menunjukkan hasil percobaan pengaruh krom pada efisiensi deposisi. Terdapat kesamaan antara grafik efisiensi deposisi dengan grafik efisiensi arus. Berdasarkan percobaan, efisiensi deposisi turun dari sekitar 6\% menjadi 1\% ketika rasio krom : nikel dinaikkan dari 3,7\% menjadi $14,8 \%$.

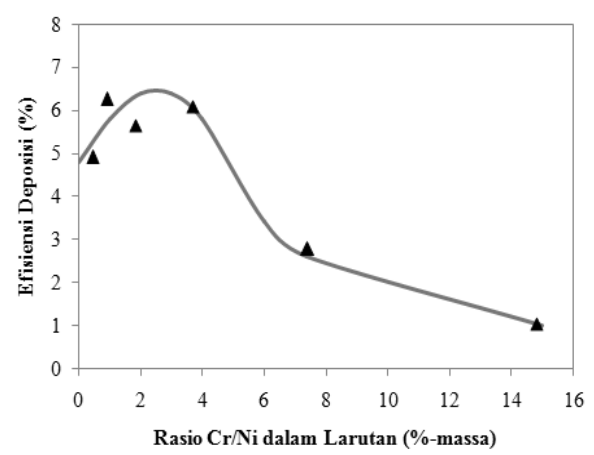

Gambar 7. Pengaruh rasio $\mathrm{Cr} / \mathrm{Ni}$ terhadap efisiensi deposisi

\subsection{Pengaruh krom terhadap kebutuhan energi listrik}

Sementara itu, kebutuhan energi listrik untuk elektrodeposisi nikel meningkat seiring dengan bertambahnya konsentrasi krom dalam larutan, seperti dapat dilihat pada Gambar 8. Sampai dengan rasio krom:nikel 3,7\%, kebutuhan energi relatif tidak jauh berbeda. Namun, pada konsentrasi yang lebih tinggi, kebutuhan energi meningkat drastis dari sekitar $3 \mathrm{kWh} / \mathrm{kg}$ nikel menjadi $11,3 \mathrm{kWh} / \mathrm{kg}$ nikel. Hal tersebut disebabkan oleh penurunan efisiensi arus serta peningkatan hambatan perpindahan muatan oleh lapisan hidroksida yang terbentuk di permukaan elektroda. Semakin tinggi rasio krom:nikel dalam larutan, pembentukan hidroksida akan semakin cepat sehingga permukaan katoda tertutupi dan mengurangi nukleasi pembentukan nikel. Oleh karena itu, kebutuhan energinya meningkat secara cepat.

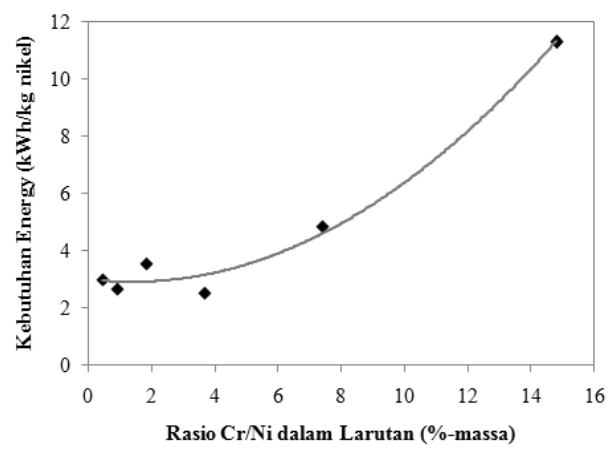

Gambar 8. Pengaruh komposisi $\mathrm{Cr} / \mathrm{Ni}$ terhadap kebutuhan energi untuk elektrodeposisi

Untuk mempelajari lebih jauh pengaruh krom, percobaan dengan menggunakan metode Design of Experiment (DOE) tipe full factorial dilakukan dengan variasi krom dan asam borat. Asam borat dipilih karena pengaruhnya yang signifikan terhadap pembentukan deposit nikel (Hoare, 1986). Krom sulfat divariasikan dengan batas atas 3,2 g/L, nilai tengah 1,65 g/L, dan batas bawah 0,2 g/L. Sedangkan batas atas Asam Borat sebesar $50 \mathrm{~g} / \mathrm{L}$, nilai tengah $43 \mathrm{~g} / \mathrm{L}$, dan batas bawah $36 \mathrm{~g} / \mathrm{L}$. Percobaan dengan nilai tengah dengan 3 kali pengulangan. Hasil analisis DOE ditampilkan dalam diagram pareto, seperti dapat dilihat pada Gambar 9 dan Gambar 10.

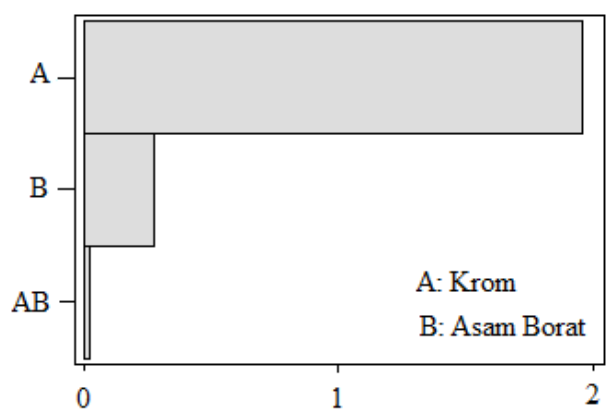

Gambar 9. Diagram pareto efek variabelvariabel percobaan terhadap efisiensi arus pada elektrodeposisi nikel 
Berdasarkan Gambar 9, terlihat bahwa efisiensi arus lebih banyak dipengaruhi oleh faktor keberadaan krom dalam larutan bila dibandingkan dengan asam borat. Sementara itu, Gambar 10 menunjukkan bahwa kebutuhan energi untuk elektrodeposisi dipengaruhi oleh krom, asam borat, maupun interaksi antara keduanya. Faktor-faktor tersebut berpengaruh pada konduktivitas larutan serta kecenderungan terbentuknya lapisan di permukaan katoda, yang pada gilirannya meningkatkan tahanan sel.

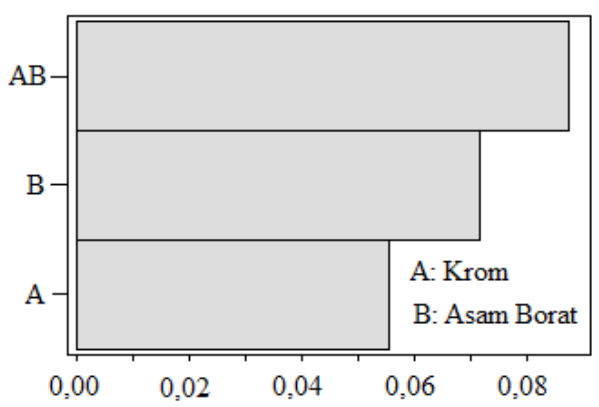

Gambar 10. Diagram pareto efek variabelvariabel percobaan terhadap kebutuhan energi untuk elektrodeposisi Nikel

\subsection{Pengaruh krom terhadap morfologi deposit nikel}

Selanjutnya, pengaruh keberadaan krom terhadap morfologi deposit logam nikel yang diperoleh, ditentukan dengan melakukan percobaan elektrodeposisi dari larutan dengan berbagai konsentrasi krom. Konsentrasi krom dalam larutan dinyatakan dalam rasio massa krom:nikel, divariasikan dari 0\% (tanpa krom) sampai dengan 14,8\%.

Elektrodeposisi dari larutan nikel tanpa krom dengan aditif magnesium sulfat, natrium sulfat, dan asam borat dapat menghasilkan endapan logam nikel yang cerah dan tebal, seperti terlihat pada Gambar 11. Melalui analisis XRD yang hasilnya dapat dilihat pada Gambar 12, diketahui bahwa endapan yang terbentuk adalah nikel murni dan tidak ada pengotor yang ikut mengendap.

Percobaan elektrodeposisi dengan larutan nikel-krom memperlihatkan bahwa keberadaan krom berpengaruh terhadap morfologi deposit nikel yang dihasilkan, sebagaimana dapat dilihat pada pada Gambar 13. Pada konsentrasi krom yang rendah (rasio krom:nikel 0,46\%), nikel yang terbentuk tebal dan mengkilap (Gambar 13.A).

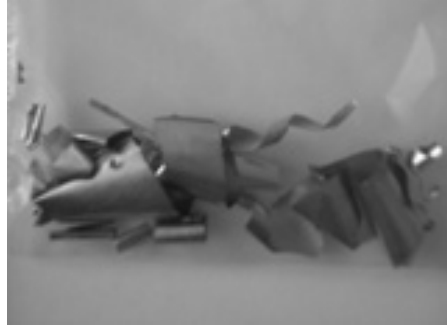

Gambar 11. Deposit nikel hasil elektrodeposisi dari larutan nikel tanpa krom

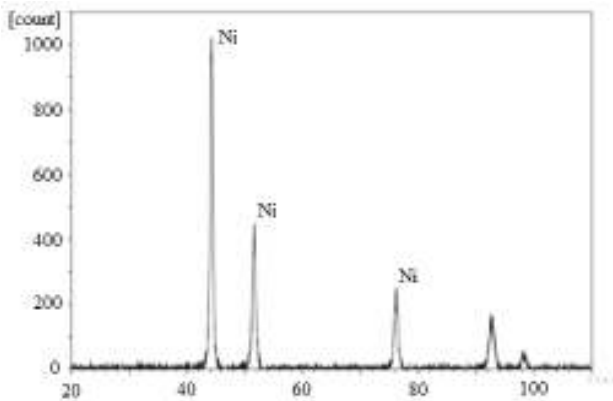

Gambar 12. Analisis XRD deposit nikel dari larutan nikel tanpa krom

Bila dibandingkan dengan deposit nikel tanpa krom pada Gambar 11, pengaruh krom terlihat dari kesinambungan lapisan nikel yang dihasilkan. Deposit nikel yang terbentuk dari larutan tanpa krom menghasilkan lapisan nikel yang kontinyu di seluruh permukaan katoda sehingga dapat dikelupas dalam bentuk lembaran-lembaran. Dengan adanya krom, lapisan yang terbentuk mulai tidak kontinyu. Hal ini dapat dilihat dari terbentuknya serpihan-serpihan kecil ketika logam nikel dilepas dari permukaan katoda.

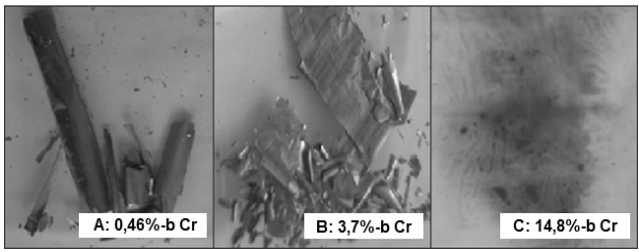

Gambar 13. Pengaruh krom dalam larutan terhadap deposit nikel hasil elektrodeposisi

Seiring dengan kenaikan konsentrasi krom dalam larutan, pengaruh krom semakin kentara. Pada rasio krom : nikel 3,7\%, lapisan logam nikel yang terbentuk menjadi lebih tipis, seperti terlihat pada Gambar 13.B. Selain itu, logam yang terbentuk mulai 
tampak kusam. Pada rasio krom:nikel 14,8\%, nikel tidak lagi terbentuk sebagai lapisan logam. Sebagai gantinya, serbuk berwarna hitam terbentuk di permukaan katoda seperti terlihat pada Gambar 13.C.

Ji dkk. (1995) menunjukkan bahwa terjadi kenaikan $\mathrm{pH}$ lokal selama proses elektrolisis. Kenaikan tersebut terutama terjadi di permukaan elektroda karena tidak dilakukan pengadukan sehingga spesi yang bereaksi tidak dapat segera digantikan oleh spesi dari fasa ruah elektrolit. Serbuk hitam yang terbentuk di permukaan katoda tersebut kemungkinan berupa kompleks ion krom (III) heksaaqua.

Ketika reaksi deposisi dimulai, pH larutan rendah, sehingga krom (III) bersama air cenderung membentuk ion kompleks tersebut. Reaksi yang berlangsung menaikkan pH larutan menuju kondisi ketika ion krom (III) heksaaqua bereaksi dengan ion hidroksida membentuk senyawa krom hidroksida kompleks yang tidak larut dalam air. Lapisan hidroksida tersebut menghalangi sebagian transfer muatan dan meniadakan nukleasi serta pertumbuhan nikel di permukaan katoda (Lantelme dan Seghiouer, 1998).

\section{Kesimpulan}

Berdasarkan hasil percobaan yang telah dipaparkan sebelumnya, dapat disimpulkan bahwa keberadaan krom meningkatkan polarisasi aktivasi, mengurangi efisiensi arus dan meningkatkan kebutuhan energi pada proses elektrodeposisi nikel. Efisiensi arus menurun drastis ketika rasio $\mathrm{Cr} / \mathrm{Ni}$ lebih besar dari $3,7 \%$. Sementara itu, kebutuhan energi meningkat secara eksponensial ketika rasio $\mathrm{Cr} / \mathrm{Ni}$ di atas 3,7\%. Kenaikan konsentrasi krom di dalam larutan elektrolit membutuhkan lebih banyak asam borat sebagai buffer pH. Efisiensi arus sangat dipengaruhi oleh konsentrasi krom sementara kebutuhan energi dipengaruhi oleh interaksi antara konsentrasi krom dan konsentrasi asam borat. Morfologi deposit nikel menjadi lebih buruk dengan kenaikan rasio $\mathrm{Cr} / \mathrm{Ni}$, dan berubah menjadi deposit hidroksida pada rasio $\mathrm{Cr} / \mathrm{Ni}$ lebih dari $14,8 \%$.

\footnotetext{
Daftar notasi

$\mathrm{E}_{\text {sel }}=$ potensial standar sel.

SHE = potensial standar hidrogen

$\mathrm{F} \quad=$ tetapan Faraday, $96500 \mathrm{C} /$ ekiv.
}

$$
\begin{aligned}
\mathrm{m}= & \text { massa senyawa yang terbentuk } \\
& \text { ataupun yang terurai, dalam gram } \\
& (\mathrm{g}) .
\end{aligned}
$$

\section{Ucapan Terima Kasih}

Penulis mengucapkan terimakasih kepada PT Pasadena Venture Indonesia, yang telah membantu pembiayaan penelitian ini.

\section{Daftar Pustaka}

Abe, S.; Gendron, A.S.; Ettel, V.A. Nickel Electrowinning Process. U.S. Patent 4,078,979, March 14, 1978.

Hoare, J. P. On the role of boric acid in the watts bath. Journal of The Electrochemical Society. 1986, 133(12), 2491-2494.

Ji, J.; Cooper, W. C.; Dreisinger, D. B.; Peters, E. Surface $\mathrm{pH}$ measurements during nickel electrodeposition. Journal of Applied Electrochemistry. 1995, 25 (7), 642-650.

Jones, D. A. Principles and Prevention of Corrosion; Macmillan Publishing Company: New York, 1992; 43.

Lantelme, F.; Seghiouer, A. Model of nickel electrodeposition from acidic medium. Journal of Applied Electrochemistry. 1998, 28(9), 907-913.

Mohanty, U. S.; Tripathy, B. C.; Singh, P.; Das, S. C. Effect of $\mathrm{Cr}^{3+}$ on the electrodeposition of nickel from acidic sulfate solutions. Minerals Engineering. 2002, 15 (7), 531-537.

Pletcher, D.; Walsh, F. C. Industrial Electrochemistry, 2nd edition; Chapman \& Hall: Glasgow, 1990; 491.

Prentice, G. Electrochemical Engineering Principles; Prentice-Hall International Inc.: New Jersey, 1991; 11.

Yin, K. M.; Lin, B. T. Effect of boric acid on the electrodeposition of iron, nickel, and Ironnickel. Surface and Coating Technologies. 1996, 78(1-3), 205-210. 